\title{
Effectiveness of Learning Material by ICT-Based Guided Inquiry Model to Train Critical Thinking Skill and Science Literacy
}

\author{
Sifak Indana ${ }^{1}$, Rudiana Agustini ${ }^{2}$, Yuni Sri Rahayu ${ }^{3}$ \\ \{sifakindana@unesa.ac.id ${ }^{1}$ \} \\ Science Education Study Program, Master Program, Universitas Negeri Surabaya ${ }^{1,2,3}$
}

\begin{abstract}
The purpose of this study was describing the effectiveness rate of learning material by ICT-based Guided Inquiry Model in training critical thinking skill and science literacy junior high school students. Before being tested, the developed learning material was assessed by an expert for the validity rate. Then, the learning material was tested on 30 seventh-grade students. This data was obtained by the critical thinking and science literacy test method. The result of this study showed that the average of the pretest was 39.9 points and the average of the posttest was 75.5 points by $\mathrm{N}$-gain score was 0.7 , categorized as a high score. That result could explain that the critical thinking skill of students was increased, from very less critical to critical. It can be concluded that learning material by ICT-based guided inquiry model was effective for training critical thinking skills and junior high school students' science literacy.
\end{abstract}

Keywords: Learning material, Guided inquiry model, ICT, Critical thinking, Science literacy, Junior high school

\section{Introduction}

Information and communication technologies (ICT) aspect is very well developed. Internet user this time reaches billion of an active user on various aspects, including education. Internet penetration in America reached 67\%, and Asia reached 10\%. The number of internet users in Indonesia in 2014 reached 83.7 million people, and it was predicted in 2017; internet users in Indonesia will reach 112 million people and beat Japan for having slower growth of internet users. The number of overall internet users in 2015 was predicted reaching 3 billion people, and in 2018, as much as 3.6 billion humans would access the internet at least for a month.

ICT has big potential to be used in education. Blueprint of Ministry of Education ICT mentions seven functions of ICT in education: (1) as learning resource, (2) learning help tool, (3) teaching and learning facilities, (4) competences standard, (5) administration system, (6) decision supporter, and (7) as infrastructure.

The availability of ICT-based learning material is a kind of support to make a class applying E-learning. The learning process can happen if the availability reaches at least two main factors: (1) learning person, and (2) learning resource. Learning resource involves person (presenter), tool (hardware), material (software), environment (setting, place taken in), etc. learning material is one of the learning resources and becomes an element that has an important role in e-learning. Learning resource is one of the essential factors in the learning process and it can be more effective if it is constructed in the form of ICT-based learning material. 
In the $21^{\text {st }}$ century, ICT has an important role in learning because of science and technology development. Then, teaching and learning activity will move from classical activity in the class to e-learning. Few of the required skills in the $21^{\text {st }}$ century is critical thinking skill and science literacy. Both of these skills are needed by an individual to explain a phenomenon scientifically and analyze a problem critically to get a solution [1].

Critical thinking is make-sense thinking and reflective, focusing to decide what should believe or do [2]. It has the same way as curriculum purposes. One of the reflective thinking components is thinking critically, as written in the 2013 curriculum. The critical thinking skill of students in Indonesia can be observed from the participation in PISA, showing that Indonesia can only reach Low International Benchmark, the lowest and weakest rate of cognitive aspect in thinking skill. Indonesia's participation in the PISA test since 2000 shows that the development of critical thinking skills has not been trained maximally by available learning material, especially ICT-based learning material.

The trend of science learning in this time - learning science as a product, memorizing concepts, principal, law, and theory only- makes science as behavior, process, and application in daily life become untouched in the learning process [3]. It needs a solution in various ways of learning that prepare students to receive science and technology; think logically, critically, creative; able arguing well; and have comprehensive thinking in real-life problem-solving.

$21^{\text {st }}$ century is a century when science literacy becomes a focus in science education. Science literacy nowadays becomes a demand in the $21^{\text {st }}$ century for being possessed by every person in daily life or in the work atmosphere. The person that is opened to science can use scientific information to solve the problem in daily life and produce useful scientific products. Program for International Student Assessment or PISA 2015 [4] explains the meaning of science literacy as a skill to involve in the problem or issues related to science/knowledge as a reflective citizen. A person that is opened to science, being able to involve, giving a reason in the discussion or science and technology discourse that needs several competencies: 1) explaining scientific phenomenon; 2) evaluating and planning scientific investigation; 3) interpreting data and scientific proof.

Science literacy is very important for being possessed by students to understand their environment, health, economy, and another kind of problem faced by modern citizens, depending on the development of science and technology. This way is similar to science education principal, increasing competences that are needed by students to fulfill their living needs [4]. Measurement of science literacy is not only for knowing students' understanding of science, but also the science process aspect, and the ability to apply science process in the real situation.

One of the learning models that can train critical thinking skills and science literacy is inquiry learning and guided inquiry learning. The inquiry learning model is more suitable for the student that has used to do an observation, while the guided inquiry learning model is for students that are still on the learning-to-observe phase. Lukman et al. [5] did this kind of study that showed the role of inquiry model by the title The Effect of the Blended Learning-based Guided Inquiry Learning to Science Literacy and Students Learning Result of Eleventh Grade Students. It concluded that blended learning-based guided inquiry learning had an effect on increasing science literacy skills and eleventh-grade students of SMAN 5 Malang's learning result.

Moreover, the study result from Avitasari et al. [6] stated that inquiry-based student worksheet for training science literacy in respiratory system material was stated as viable, according to the validity, practicality, and effectiveness. 
The teaching book was stated as valid for having a score of 3.66 points, according to teaching book validation (with content, language, and presentation factor) [7]. The question developed from that study was stated as valid for having a score of 3.93 points. Readability of that book, using Fry Graphic, was categorized in eleventh grade, suitable with students' class rate. It was concluded that the science literacy-based teaching book immunity system was stated as valid and suitable for students' class rates.

Learning material with a guided inquiry model will give an amazing learning experience. Technology aspect that is near to internet users and giving chance to students to find their own concept become two icons in one teaching and learning activity. Generally, the main themes and main part of learning material can be planned in the curriculum for facing a global challenge: (1) life skill and another skill need in scarier development; (2) learning and innovating skills;

(3) applying information and communication technology skill [8].

The inquiry process has an important role in daily life. Inquiry can be interpreted as a process to answer and solve problem-based on facts and observations. From the teaching and learning aspect, the inquiry is a strategy of teaching/learning, designed to teach students how to investigate/observe problems and questions using facts [9].

Inquiry learning can learn strategy and skill that can be used in another situation when certain information is needed. Similarly, independence in this inquiry process is also developing several skills of students, including thinking skills such as finding information, processing information, deciding smartly, and solving problems creatively.

Learning to train critical thinking skills and science literacy should be done at all school levels after knowing how important those two skills are, to prepare students facing the $21^{\text {st }}$ century, including one-stop school. One-stop school is a school that manages elementary school and junior high school in the same building. Moreover, research is needed to describe the effectiveness of learning material with an ICT-based guided inquiry model to train critical thinking skills and science literacy to students of SMPN Satu Atap Kenduruan.

\section{Methods}

This research used a descriptive quantitative method that was done in SMPN Satu Atap Kenduruan. This research used 30 students of seventh grade that had not got the lesson of living creature and environment interaction yet.

The trial of learning material was done by using One Group Pretest and Posttest Design. The trial was started by doing a pretest $(\mathrm{O} 1)$. Then, students were given treatment by learning using learning material with an ICT-based guided inquiry model (X). Lastly, the posttest was done $(\mathrm{O} 2)$. The plan of learning material trial can be drawn as below:

\begin{tabular}{|lll|}
\hline $\mathrm{O}_{1}$ & $\mathrm{X}$ & $\mathrm{O}_{2}$ \\
\hline
\end{tabular}

Note:

O1: pretest for knowing students' ability before learning started

$\mathrm{X}$ : treatment/learning process using developed material

O2: posttest for knowing critical thinking skill and science literacy after learning

The treatment given to train students' critical thinking skills and science literacy was by implementing ICT learning that utilizes technology during the learning process. ICT implemented was integrated with the inquiry learning syntax which includes (1) Problem 
orientation, (2) Formulating Problems, (3) Formulating hypotheses, (4) Identifying variables, (5) Designing experiments, (6) Conducting experiments, (7) Presenting data, (8) Analyzing data, (9) Summing up the results of an experiment, and (10) Communicating the results of an experiment.

The effectiveness of learning material in this trial was observed from the test of students' critical thinking and science literacy. The test instrument used to assess students' critical thinking skills and science literacy was the same test instrument. The test instrument consisted of 5 item description. The item used requires students to think critically in accordance with 5 indicators of critical thinking, namely (1) Formulating the problem, (2) Giving an argument, (3) Doing induction, (4) Conducting an evaluation, and (5) Deciding an action. In addition to requiring students to think critically, the test instrument also contains 3 aspects of science literacy, namely the content of science, the process of science, and the context of the application of science.

\section{Results and Discussion}

The effectiveness of learning material in this trial was observed from the result of critical thinking and science literacy test. Data gained consists of one data. The pretest result was used to know the initial ability of students' critical thinking and science literacy before giving the treatment. Meanwhile, the posttest result from students was used to know critical thinking and science literacy ability that had been possessed by students after following the learning process with a guided inquiry model in living creatures and environment interaction lessons.

The data obtained from the pretest and posttest was in the form of students' critical and science literacy skills. Data on students' critical thinking and science literacy skills was a unity because the test instruments used to measure both of them were the same instrument. With a note that the test instrument included indicators of critical thinking, namely (1) Formulating the problem, (2) Giving an argument, (3) Conducting an induction, (4) Conducting an evaluation, (5) Deciding an action and also included of science literacy aspects, namely (1) science content,

(2) science process, and (3) science application context.

Pretest and posttest results of critical thinking and science literacy of SMPN Satu Atap, Kenduruan, can be seen in Table 1.

Table 1. Pretest and posttest result of critical thinking and science literacy in SMPN Satap Kenduruan.

\begin{tabular}{|c|c|c|c|c|c|c|c|}
\hline No & $\begin{array}{l}\text { Student's } \\
\text { Initial }\end{array}$ & Pretest & $\begin{array}{l}\text { Resul } \\
\text { Category }\end{array}$ & $\begin{array}{c}\text { Post- } \\
\text { test }\end{array}$ & Category & $\begin{array}{c}\text { N- } \\
\text { Gain }\end{array}$ & Category \\
\hline 1. & $\mathrm{~S} 1$ & 50.00 & Less Critical & 62.86 & Critical & 0.3 & Moderate \\
\hline 2. & $\mathrm{~S} 2$ & 42.86 & Very Less Critical & 78.57 & Critical & 0.8 & High \\
\hline 3. & S 3 & 42.86 & Very Less Critical & 72.86 & Critical & 0.6 & Moderate \\
\hline 4. & $\mathrm{~S} 4$ & 50.00 & Less Critical & 80.00 & Critical & 0.8 & High \\
\hline 5. & S 5 & 35.71 & Very Less Critical & 70.57 & Critical & 0.6 & Moderate \\
\hline 6. & S 6 & 21.43 & Very Less Critical & 65.71 & Critical & 0.6 & Moderate \\
\hline 7. & $\mathrm{~S} 7$ & 42.86 & Very Less Critical & 75.71 & Critical & 0.7 & High \\
\hline 8. & S 8 & 42.86 & Very Less Critical & 72.86 & Critical & 0.6 & Moderate \\
\hline 9. & S 9 & 14.29 & Very Less Critical & 65.71 & Critical & 0.7 & High \\
\hline 10. & S 10 & 42.86 & Very Less Critical & 78.57 & Critical & 0.8 & High \\
\hline
\end{tabular}




\begin{tabular}{|c|c|c|c|c|c|c|c|}
\hline \multirow[b]{2}{*}{ No } & \multirow[b]{2}{*}{$\begin{array}{l}\text { Student's } \\
\text { Initial }\end{array}$} & \multirow[b]{2}{*}{ Pretest } & \multicolumn{2}{|c|}{ Result } & \multirow[b]{2}{*}{ Category } & \multirow{2}{*}{$\begin{array}{c}\mathrm{N}- \\
\text { Gain }\end{array}$} & \multirow[b]{2}{*}{ Category } \\
\hline & & & Category & $\begin{array}{l}\text { Post- } \\
\text { test }\end{array}$ & & & \\
\hline 11. & S 11 & 50.00 & Very Less Critical & 85.71 & $\begin{array}{l}\text { Very } \\
\text { Critical }\end{array}$ & 0.9 & High \\
\hline 12. & S 12 & 42.86 & Very Less Critical & 85.71 & $\begin{array}{l}\text { Very } \\
\text { Critical }\end{array}$ & 0.9 & High \\
\hline 13. & S 13 & 21.43 & Very Less Critical & 65.71 & Critical & 0.6 & Moderate \\
\hline 14. & S 14 & 42.86 & Very Less Critical & 82.86 & Critical & 0.8 & High \\
\hline 15. & S 15 & 42.86 & Very Less Critical & 85.71 & $\begin{array}{l}\text { Very } \\
\text { Critical }\end{array}$ & 0.9 & High \\
\hline 16. & S 16 & 50.00 & Less Critical & 90.00 & $\begin{array}{l}\text { Very } \\
\text { Critical }\end{array}$ & 1.0 & High \\
\hline 17. & S 17 & 35.71 & Very Less Critical & 72.86 & Critical & 0.7 & High \\
\hline 18. & S 18 & 28.57 & Very Less Critical & 55.71 & $\begin{array}{l}\text { Less } \\
\text { Critical }\end{array}$ & 0.4 & Moderate \\
\hline 19. & S 19 & 50.00 & Very Less Critical & 82.86 & Critical & 0.8 & High \\
\hline 20. & S 20 & 35.71 & Very Less Critical & 65.71 & Critical & 0.6 & Moderate \\
\hline 21. & S 21 & 50.00 & Less Critical & 80.86 & Critical & 0.8 & High \\
\hline 22. & S 22 & 50.00 & Less Critical & 70.71 & Critical & 0.5 & High \\
\hline 23. & S 23 & 50.00 & Less Critical & 85.71 & $\begin{array}{l}\text { Very } \\
\text { Critical }\end{array}$ & 0.9 & High \\
\hline 24. & S 24 & 42.86 & Very Less Critical & 70.00 & Critical & 0.6 & Moderate \\
\hline 25. & S 25 & 42.86 & Very Less Critical & 83.71 & $\begin{array}{l}\text { Very } \\
\text { Critical }\end{array}$ & 0.9 & High \\
\hline 26. & S 26 & 42.86 & Very Less Critical & 72.86 & Critical & 0.6 & Moderate \\
\hline 27. & S 27 & 50.00 & Less Critical & 82.86 & Critical & 0.8 & High \\
\hline 28. & S 28 & 14.29 & Very Less Critical & 60.00 & Critical & 0.6 & Moderate \\
\hline 29. & S 29 & 42.86 & Very Less Critical & 82.86 & Critical & 0.8 & High \\
\hline 30. & S 30 & 35.71 & Very Less Critical & 85.71 & $\begin{array}{l}\text { Very } \\
\text { Critical }\end{array}$ & 0.9 & High \\
\hline \multicolumn{2}{|c|}{ Average } & 39.9 & Very Less Critical & 75.71 & Critical & 0.7 & High \\
\hline
\end{tabular}

In Table 1., the pretest and posttest result of every student and result achievement of every student is presented in N-gain. That result can explain that the critical thinking skill of students in SMPN Satu Atap Kenduruan was increased from very little critical to critical. Less supportive environment makes students become less motivated in studying. Most of the students coming to school are only to fulfill their obligation to their parents. Several students barely can read. School facilities are not adequate (school building still merged to elementary school building). It makes teaching and learning activity becomes disturbed. Added by a learning schedule that should be started in the afternoon makes several students asleep and easily gets bored because of an obligation for helping their parents working in the field. Furthermore, the distance between the house and school is far. It makes the student needs to go home faster. It also happened to science literacy that got high increasing.

Students did not directly possess critical thinking skills and science literacy. Students can possess both of these skills by training consequently. According to Light and Cox (2001), in Indana (2008), even though human has cognitive potential since the newborn, a human is not completed by empirical knowledge or methodology rules on the mind. A human never gets complete knowledge or instant package of knowledge. All of the knowledge, methods to understand, and various disciplines in citizenship were built by the human mind. 
Increased students 'critical thinking skills along with increasing students' science literacy. Given the test of critical thinking skills and science literacy using the same instrument. The increase was due to the learning done. The learning was carried out by implementing ICT based guided inquiry learning. Hanafi et al. (2017) stated that ICT has a positive effect on learning, where ICT can improve students' motivation in learning. With increased students' motivation, it will have an impact on students' understanding concepts. In addition ICT learning that implemented was based on inquiry learning. Where this inquiry learning has an impact on students' critical thinking skills and science literacy.

Critical thinking skill results in this research are corresponding with research done by Kitot et al. (2010). It was stated that inquiry-based learning was effective to increase the critical thinking skill of students. Greenwald and Quitadamo (2014) stated that inquiry-based learning was an alternative solution for conventional learning to increase critical thinking skills and clinical reasoning of students. Thaiposri and Wannapiroon (2014) stated that inquiry-based learning could help students to develop their critical thinking skills. Sutama et al. (2014) concluded that there was increasing in students' critical thinking skills by applying the inquiry learning model than a direct learning model.

\section{Conclusion}

According to the research result and discussion, it can be concluded that the ICT-based guided inquiry-learning model effectively trained critical thinking skill and science literacy of junior high school students with $\mathrm{N}$-gain average on high category.

\section{References}

[1] Daniel, B. R.: Defining Critical Thinking for the 21st Century World Language Classroom. All Theses and Dissertations. 4288. (2013)

[2] Ennis, R.H.: Critical Thinking. United State of America: Prentice-Hall (1996)

[3] Inzanah, I., Ibrahim, M., dan Widodo, W.: Pengembangan Perangkat Pembelajaran IPA Berbasis Kurikulum 2013 Untuk Melatih Literasi Sains Siswa SMP (Developing Science Learning Material Based on curriculum of 2013 to train junior high students' science literacy). Pendidikan Sains Pascasarjana Universitas Negeri Surabaya. Vol. 4 No. 1 (2014)

[4] OECD.: Survey International Program for International Student Assessment (PISA). (Online) (http: // www.oecd.org/pisa) (2013)

[5] Lukman, Y., Suwono, H., \& Suarsini, E.: Pengaruh Pembelajaran Inkuiri Terbimbing BerbasisBlended Learning Terhadap Literasi Sains Dan Hasil Belajar Siswa Kelas XI SMA Negeri 5 Malang (The Effect of Blended Learning-based Guided Inquiry Learning to Science Literacy and Result of Eleventh Grade of SMA Negeri 5 Malang). Universitas Negeri Malang (2013)

[6] Avitasari \& Indana.: Pengembangan LKS berbasis inkuiri untuk melatihkan literasi sains pada materi sistem pernapasan (Developing Inquiry-Based Student Work Sheet to Train Science Literacy in Respiratory System Lesson) (unpublished thesis). Surabaya: Universitas negeri Surabaya. (2016)

[7] Savitri, Inne \& Indana.: Pengembangan Buku ajar Berbasis Literasi Sains pada Materi Sistem Imun untuk Melatihkan Keterampilan Berpikir Critical Siswa Kelas XI SMA (Developing Science Literacy Teaching Book in Immunity System Lesson to Train Critical Thinking Skill). (unpublished thesis). Surabaya: Universitas Negeri Surabaya. (2017)

[8] Suyono dan Hariyanto.: Belajar dan Pembelajaran: Teori dan Konsep Dasar (Learn and Learning: Theory and Basic Concepts). Bandung: PT. Remaja Rosdakarya. (2011) 
[9] Kardi, S.: Pengantar pengembangan kurikulum dan rencana pelaksanaan pembelajaran (Introduction of Developing Curriculum and Lesson Plan). Surabaya: Program Pascasarjana Universitas Negeri Surabaya. (2012) 